https://doi.org/10.31874/2520-6702-2020-9-1-3-14

УДК $378.1+37.015 .5(4+44)$

\title{
Debych Mariia
}

\section{The Triggers for Internationalization and Quality Enhancement in Higher Education of France ${ }^{1}$}

\begin{abstract}
The article analyzes the internationalization strategies and the quality assurance systems of France and Université de Lorraine. It has been found out that the goals, proposed in the national and institutional internationalization strategies, include strengthening policies to improve the reception of international students, young researchers and staff.

It has been noted that Haut Conseil de l'évaluation de la recherche et de l'enseignement supérieur and Université de Lorraine are partners in the project «Implementation of Education Quality Assurance System via Cooperation of University-Business-Government in Higher Education Institutions» (EDUQAS Project), aiming at improving education quality assurance systems through the development of efficient internal quality standards leading to graduates' better employability in partner countries.

Haut Conseil de l'évaluation de la recherche et de l'enseignement supérieur and Commission des Titres d'Ingénieur are authorized to conduct international accreditations of study programs. Université de Lorraine Délégation à l'Aide au Pilotage et à la Qualité promotes a culture of continuous improvement and organizational development based on the tools of quality management and process control.

It has been noted that participation in EDUQAS Project stimulates further development of QA systems at the national and institutional levels; wider participation of stakeholders in higher education quality enhancement and internationalization; higher education quality monitoring through stakeholders' surveys; monitoring graduates' career paths in partner countries.

The legislative basis, internationalization strategies and quality assurance institutions at the national and institutional levels, networks of stakeholders involved in internationalization and quality assurance processes, participation in the international projects have been identified to be triggers for internationalization and quality enhancement in higher education of France.

Key words: internationalization strategy, quality assurance system, Délégation à l'Aide au Pilotage et à la Qualité (DAPEQ), EDUQAS Project, self-assessment report, study program.

\section{Introduction}

Quality assurance has been one of the main issues being discussed at the Bologna Process meetings of ministers responsible for higher education. At the meeting in Paris on May 24-25, 2018, the ministers responsible for higher education confirmed the progress, made in building the European Higher Education Area (EHEA) over the past two decades: implementation of goals and policies agreed upon at the European level in the national education systems and higher education institutions (HEI); common landscape of higher education in the EHEA; large-scale student mobility; improved comparability and transparency of the higher education systems; increased higher

\footnotetext{
${ }^{1}$ This article has been prepared within the framework of Erasmus+ project «Implementation of Education Quality Assurance System via Cooperation of University-Business-Government in higher education institutions» (2017-2020) and specifically the visit to Université de Lorraine, March 12-14, 2019. The author expresses her deep gratitude to Cédric Sanlis (Université de Lorraine) and Solange Pisarz (Haut Conseil de l'évaluation de la recherche et de l'enseignement supérieur) for their support and materials that have been used in preparation of this article.
} 
education quality and attractiveness. In short, the EHEA has promoted mutual understanding and trust, and has enhanced cooperation among the higher education systems. "Quality assurance is key in developing mutual trust as well as increasing mobility and fair recognition of qualifications and study periods throughout the EHEA» (Paris Communiqué, 2018).

The progress has been made in implementing the "Standards and Guidelines for Quality Assurance in the European Higher Education Area» (ESG, 2015) into national and institutional practice in most countries. At the same time strong and ambitious commitments for the further development have been made: to remove the remaining obstacles to their implementation in the national legislations and regulations; to encourage the development of more joint programs and joint degrees; to enable and promote the use of the «European Approach for Quality Assurance of Joint Programs» (European Approach for Quality Assurance of Joint Programmes, 2014) in the higher education systems; to promote the development of the Database of External Quality Assurance Results (DEQAR) (Paris Communiqué, 2018).

A project «Implementation of Education Quality Assurance System via Cooperation of University-Business-Government in Higher Education Institutions» (EDUQAS Project), aiming at improving education quality assurance systems through the development of the efficient internal quality standards, leading to graduates' better employability in partner countries, was launched in February 2018, with the University of Craiova (Romania) being the grant holder and project coordinator.

The project is running over 2017-2020 and is being implemented by a multinational and multidisciplinary team bringing together educators from different fields: Economics, Business Administration, Electrical Engineering, Humanities and Sciences, and Information Technology.

This project aims to implement the European quality assurance policies in higher education in non-EU countries, and has 29 partner institutions from Belgium, Bulgaria, France, Kazakhstan, Latvia, Romania, Sweden, and Ukraine.

Expected results of this project are the following: established quality assurance units, developed set of standards, guidelines for internal quality assurance in higher education; improved quality of activities (research, education, governance) on the basis of the study of procedures and processes of the European Union (EU) universities; improved quality culture among students, academic staff, management and administration of the University; developed affiliate network University-Business-State through cooperation of the Quality Assurance Agencies (QAA), professors, researchers, students with the EU universities; enhanced internal university information systems of quality evaluation and corporate quality assurance (QA) infrastructure (Erasmus+ K2A project, 2018).

Haut Conseil de l'évaluation de la recherche et de l'enseignement supérieur (HCERES) and Université de Lorraine (UL) represent France in EDUQAS Project.

The purpose of the article is to identify and disseminate the valuable French experience in quality assurance and internationalization, obtained during implementation of EDUQAS Project.

Research aim of the article is to demonstrate the coherence between external and internal systems of quality assurance in higher education of France and identify elements that trigger enhancement of higher education quality and internationalization.

\section{Research methods}

To achieve the above aim, several methods have been used, including a site visit ${ }^{2}$, interviews, internet search, analysis, systematization of evident information.

2 In addition to Université de Lorraine, in 2019-2020 three site visits to the Ukrainian HEls were held with the aim to assess their internal quality assurance systems against the EHEA principles and procedures, ESG, and EDUQAS practices (http://web.elth.ucv.ro/eduqas). 


\section{Research results}

France has high standards of higher education and research. Research institutions and HEls continue promoting the country's international attractiveness. The level of international collaboration in scientific publications is one of the highest in the world ( $47 \%$ of all publications are with international partners) (de Wit, Hunter, Howard, Egron-Polak, 2015).

In 2019, there were 5,3 million international students in the world, 5\% of them studied in France. The international students make up $12,8 \%$ of the total France higher education population (Project Atlas Infographics, 2019).

The Shanghai ranking (2019) shows 3 French universities in the top 100 and 21 universities in the top 500 (ARWU, 2019).

The French system of higher education and research is characterized by a marked degree of internationalization: a high level of international partnership in research; focus on attracting qualified talent, not for purely commercial reasons; capacity building in the former French colonies; governmental support for academic mobility; active participation in the European projects; a wide network of French establishments abroad (Debych, 2019, p. 129-130).

International cooperation forms an integral part of the mission statement of universities, having been enshrined in Law Faure since 1968 (Loi Faure 1968), Law Savary (Loi Savary, 1984). The concept was extended to include the development of the EHEA, and the most recent Law on Higher Education and Research (Law on Higher Education and Research, 2013) regulates new areas of internationalization, such as the possibility to deliver curricula in foreign languages.

As an EU member state, France has been a participant of Erasmus since 1987 and joined the EU Erasmus+ Program in 2014. The main objectives of the Program are to enable citizens to acquire professional competences, promote multilingualism and European citizenship. It should be noted that France has high rates of mobility, especially inbound (L'agence Erasmus+ France).

In France, la Stratégie Nationale de l'Enseignement Supérieur (StraNES) was adopted in autumn 2015. «It involves a clear international dimension, setting quantitative benchmarks by 2025 for doubling inbound and outgoing mobility, strongly encouraging Master students to go abroad, broadening international education programs including the development of Massive Open Online Courses (MOOCs), improving students' foreign-language skills, and improving the organization of international cooperation projects. Some of the strategic goals proposed at the national and institutional levels include strengthening national policies to improve the reception of international students, young researchers and staff; promoting outgoing mobility by strengthening the National Mobility Agency (Campus France); introducing educational programs in foreign languages» (Bologna Process Implementation Report, p. 242).

To conclude, French strategy for the internationalization of higher education has been built on the principles of cooperation of all stakeholders and legislative background. The country's attractiveness for international students proves the high quality of education in France.

France's quality assurance efforts in education began in 1984 with the establishment of Comité national d'évaluation (CNE), an autonomous administrative unit that reported directly to the French President. Its mission was to evaluate universities, schools, and other institutions in the education sector (CNE, les missions et les principes d'action).

Two education laws, the Act on Research (2006) and the Act on the Liberties and Responsibilities of Universities (2007) were passed by the French government to enable France's participation in the Bologna Process, and ensure that its quality assurance standards are met. To meet these higher standards CNE was replaced by Agence d'évaluation de la recherche et de l'enseignement supérieur (AERES). AERES is responsible for the evaluation of institutions such as universities, grandes écoles, and research organizations. It is also responsible for evaluating the 
research units of the French National Centre for Scientific Research, as well as bachelor, master, and doctoral programs. Each category has different evaluation process (AERES).

Haut Conseil de l'évaluation de la recherche et de l'enseignement supérieur, created by the Law on Higher Education and Research (2013) relative to higher education and research, replaced the AERES from November 17th, 2014. HCERES has independent administrative authority status, is directly funded by Parliamentary vote and is financially monitored only by the French Court of Auditors (HCERES).

HCERES manages 3 types of evaluation for each $\mathrm{HEI}$ on a 5 -year basis. A detailed description of evaluation procedure has been presented by Cédric Sanlis (UL, responsable de la sous-direction management par la qualité) and Solange Pisarz (HCERES) in the framework of EDUQAS Project visit to UL in 2019. 3 types of evaluation for each HEl are the following (Sanlis, Pisarz, 2019):

- Institutional evaluation: positioning, strategy, organization, governance, management.

- $\quad$ Research units: quality of research activities and products, organizational structure and general activities, five-year strategy and development plan.

- Study programs: 1. Outcomes of the study program. 2. Position of the study program. 3. Pedagogical organization of the study program. 4. Management of the study program.

For external assessment of the study programs HCERES requires: HEI splits the whole diploma offer by cluster; self-assessment by cluster; self-assessment document for each study program. Clusters creation facilitates the evaluation of the university's training strategy by HCERES. It is also an opportunity for the institution to check the coherence of its training offer.

1. Outcomes of the study program (Sanlis, Pisarz, 2019):

1.1. The study program has explicit objectives with regard to knowledge and skills to be acquired (outcomes description text, skills based approach development level).

1.2. Outcomes in terms of job opportunities and further studies are explicitly stated (the study program is a part of the national system of certifications (professionnal skills list, job type, education level)).

2. Position of the study program (Sanlis, Pisarz, 2019):

2.1. The study program states its position in the local, regional, national or international environment, as applicable (position in the cluster / list of corresponding programs).

2.2. Clear link between the study program and research (research units linked (master degree) / research training activities (bachelor degree)).

2.3. Relationships with businesses, associations and other cultural or industrial partners, including international partners (list of partners and support letters).

2.4. States the added value of its partnerships with foreign HEls (list of partners and detailed explanation about added value and partnership agreement, student international mobility opportunities).

3. Pedagogical organization of the study program (Sanlis, Pisarz, 2019):

3.1. The structure of the study program is adapted to the different student academic pathways (courses units list, optional courses, gradual specialization; list of pathways: lifelong learning, apprenticeship, possibility of scheduling (workers, disabled persons, high-level athlete).

3.2. The content of the study program is consistent with the national framework (linked with the socioeconomic needs); training to real-life professional situations, foreign language acquisition, professional environment knowledge courses.

3.3. Projects and internships are a key teaching tool with specific support mechanisms (description of project, internship duration: ECTS value, internship's agreement). 
3.4. The study program allows students to acquire additional skills that are useful for employment or further study; skills certification access, entrepreneurship, Diploma Supplement.

3.5. The study program encourages the use of digital technologies and other innovative teaching methods (innovative teaching methods description (serious games for example), digital platform uses).

3.6. The study program offers specific tools for successful program completion (personalized follow-up, upgrading courses).

3.7. The study program prepares students for the international environment (foreign language instruction, international student mobility framework).

3.8. The study program fulfills French worker skill based recognition system (specific French system already exists for whole national diploma).

3.9. The study program raises awareness to scientific integrity of the ethical dimension and promotes corresponding best practice (anti-plagiarism system, anti-fraud concern, ways to provide information on ethical values).

4. Management of the study program (Sanlis, Pisarz, 2019):

4.1. The study program is implemented by a formally identified teaching team (list of the teachers and their qualification and administration staff).

4.2. The management methods are based on a planned organization to which students and training actors contribute (pedagogical team meeting organization, Development Council minutes).

4.3. Knowledge is assessed according to specifically stated methods communicated to students (knowledge and skills assessment rules, explicit awarding ECTS credits).

4.4. The study program works to monitor skills acquisition (skills based approach development level, skills portfolio).

4.5. Student numbers and the different enrolment regimes for the study program are clearly identified (pedagogical statistics uses, academic results analysis / statistical annex).

4.6. The study program has complete information on graduate's path (graduate's path analysis / statistical annex).

4.7. The study program has comprehensive information on graduate's professional integration (graduates jobs or study pursuits are analyzed).

4.8. Quality assurance (Development council minutes, courses assessment system description).

The periodic self-assessment of the study programs at UL is prepared by the quality assurance office: documentation based on HCERES requirements (the criteria evolve each years, but its always based on ESG) is prepared according to the needs of training office direction colleagues; each responsible of program recieves the documents and explanation (strict scheduling of the process is crucial); a self-assessment committee is created and include elected representatives of each training field and elected representatives of the training council; facilitators are appointed by the self-assessment committee for each cluster and type of degree, they work directly with diploma responsibles (Sanlis, Pisarz, 2019).

Each self-assessment report is evaluated by 2 members of the committee, the purpose is to improve the quality of the self-report: text description, factual analysis, evidences. Two outcomes of evaluation are possible: 1 . The report shows that the study program does not fit the requirements: political alert to stop it and work on a new study program. 2 . The report proves that the study program fits the requirements: diploma responsible receives recommendations and uses them to improve own report (Sanlis, Pisarz, 2019).

HCERES evaluates agencies or foreign institutions in Europe and at international level (Saudi Arabia, Armenia, and Vietnam); provides expertise to foreign agencies in creation or development (Lebanon, Morocco); participates in the European and international networks (European 
Association for Quality Assurance in Higher Education (ENQA), International Network for Quality Assurance Agencies in Higher Education (INQAAHE), G8 Research Group, European University Association (EUA)); develops a network of cooperation with equivalent foreign agencies (NIADE-UE in Japan, CNA in Colombia, CONEAU in Argentina, CONSUAN in Andin countries, CEEC in Québec, VISTEC in Vietnam) (HCERES; ENQA, members).

In France, there is another quality assurance body responsible for evaluation and accreditation of higher education institutions for training professional engineers - Commission des Titres d'Ingénieur (CTI) (Historie et la missions de la CTI). It was established in 1934 by the French law as an independent commission whose members are both professionals from industry and academics. CTI's mission is the accreditation of engineering programs in France, and abroad upon demand. The objective of CTI's accreditation is twofold (Historie et la missions de la CTI):

1. To guarantee that engineering degrees are delivered according to appropriate quality standards.

2. To ensure that the final competence profile of engineering graduates enables entry to the engineering profession.

$\mathrm{CTI}$ is authorized by French law to accredit programs in France and abroad. These programs obtain recognition by the French government. CTI is active in several European and non-European countries (Belgium, Bulgaria, Burkina Faso, China, Switzerland, and Vietnam). Apart from international accreditation activities, CTI is a member of ENQA, European Consortium for Accreditation (ECA), Francophone network of quality assurance agencies (FrAQ-Sup), and European Network for Accreditation of Engineering Education (ENAEE). It is one of the 14 agencies entitled to deliver a European quality label for engineering studies (EURACE label) (ENQA, members).

The detailed analysis of the quality assurance agencies indicates that higher education quality enhancement is being paid constant attention to at the national level.

Within EDUQAS Project, the author of the article has visited Universite de Lorraine to learn how quality assurance system is being managed at the institutional level. Université de Lorraine was established on January 1, 2012 by the merger of Henri Poincaré, Nancy 2 and Paul Verlaine Universities, and the National Polytechnic Institute of Lorraine (INPL) and other HEls with the aim to unify the main colleges of Lorraine region. The merger process started in 2009 with the creation of a "pôles de recherche et d'enseignement supérieur» or PRES. The university is divided into two university centers, one in Nancy (biological sciences, health care, administration, computer science, and management) and one in Metz (material sciences, technology, and management). UL has over 60,000 students and has 101 accredited research centers organized in 9 research areas and 8 doctoral colleges. UL possesses 301-400 in ARWU ranking (Université de Lorraine, portrait).

$U L$ has a large spectrum of international activities: inbound and outgoing student exchanges (about 1,500 of students spend at least one semester abroad during their studies, 15\% of students started their studies in one among approximately 100 foreign countries); 60 joint diplomas, including 7 Erasmus Mundus master programs (International Strategy).

Research collaborations of UL are the following: numerous joint PhDs ( $11 \%$ of PhDs are shared with a foreign university); joint groups or labs with foreign universities. Nearly $30 \%$ of publications are co-signed with scientists from other countries (International Strategy).

Mobility of students, PhD students, post-docs, faculty members and administrative staff consolidates international integration. UL has an active policy for encouraging outgoing mobility and facilitates and simplifies the welcome of incoming persons. UL supports researchers in the internationalization of research, whether from abroad or a Lorraine researcher in search of international development, or mobility in the context of research (International Strategy).

With nearly 10,000 international students, UL is widely open to the world, whether through bilateral agreements, cooperation agreements, European (Erasmus+) or international programs. 
Independent students "outside the program» are also welcomed and all benefit from the same attention and support from the specialized reception service - Accueil International. At the start of the new academic year Accueil International informs upon arrival of all the practical aspects (accommodation, transport, etc.) to help students settle in Lorraine (Welcome to Université de Lorraine).

UL has a Délégation à l'Aide au Pilotage Et à la Qualité (DAPEQ). A true design, consultancy and expertise office made up of a dozen managers, DAPEQ promotes a culture of continuous improvement and organizational development based on the tools of quality management and process control. The web page describes its mission and functions in the following way (https://www.univ-lorraine.fr/content/aide-au-pilotage-et-\%C3\%A0-la-qualit\%C3\%A9):

The mission of DAPEQ:

- $\quad$ Decision support engineering - Design office, advice, expertise.

- $\quad$ Conceptual advice and support to decision makers.

- Analysis and design of tools: design and develop: the strategic dashboard, the various decision-making and operational dashboards linked to the business lines and analysis; carry out all statistical surveys aimed at supplementing knowledge of the themes, related to the missions of the university, analysis, prospectus; develop evaluation procedures, the results of which will help guide the policies to be implemented.

- Contribution to the completeness and consistency of the information system classifications and to the quality of the data.

- $\quad$ Promote the quality approach in all areas of university activity.

- $\quad$ Audit, expertise and advice in quality management.

The 3 poles of DAPEQ are the following:

- Management Control and Economic Analysis:

management control; internal audit; budget forecasts and monitoring budget execution; performance analysis via indicators and cost monitoring; retrospective and forecast economic studies; dashboards.

- University Life Observatory:

expertise and advice in the design of decision support tools and carrying out of statistical surveys, analyses; study of the course and the future of the students; publications.

The role of University Life Observatory is to collect, analyze, and communicate data and indicators, related to students' paths during their studies and after graduation. Monitoring students' paths has become a major concern for French higher education due to national incentives (Leveratto, Schmitt, and Barad, 2019). Law on Liberties and Responsibilities of Universities (LRU or Law Pécresse) is the official name of a French law aiming at revamping entirely the French public higher education system. The law was presented by the French Ministry of Higher Education Valérie Pécresse and was officially voted on August 11, 2007 by the Parliament. According to this law professional integration becomes an assential mission of universities, besides training and research. Article 20 of the LRU reads: "Institutions offering courses leading to a diploma of higher education must practise statistics that contain indicators of success in examinations and degrees, further education and the professional integration of their graduates" (Leveratto, Schmitt, and Barad, 2019).

The law, called Orientation et Réussite des Étudiants (ORE), came into force in September 2018, places student success at the heart of the system of higher education. Article 7 of the ORE reads: "Statistics containing the students' professional integration rates, observed one year and two years after graduation, are published on the institution's website (...) they are examined when the institution of higher education applies for its degree courses to be accredited (...). Each student 
must be informed before beginning a new program or putsuing higher education». Statistical data collected during the survey are centralized at a national level for their exploitation by the ministry. They are used as a steering tool for university and taken into account in the evaluation of universities. There are two ways of collecting the information: by Internet (Computer Assisted Web Interview, CAWI) and by telephone (Computer Assisted Telephone Interview, CATI) (Sanlis, 2019).

- $\quad$ Quality Management:

support for the establishment's strategic project; external / internal evaluation in connection with agencies (HCERES, CTI); support for the establishment of an internal quality assurance system in the fields of training, research and governance; animation of the Quality Improvement Resource Center (CRAQ); assessment of lessons; consulting, audits, expertises.

DAPEQ is a member of numerous networks (Réseau Qualité Enseignement Supérieur et Recherche (RELIER), Réseau des Observatoires de l'enseignement Supérieur (RESOSUP), Réseau d'Aide au Pilotage de l'Enseignement Supérieur (RAPESUP), Qualité en Recherche et Enseignement Supérieur (QuaRES), Qualité en Recherche (QeR)), and participates in working groups Agence de Mutualisation des Universités et Établissements (AMUE), La Conférence des présidents d'université (CPU) (Université de Lorraine, DAPEQ).

So, quality assurance system at the institutional level is a well-structured unit responsible for quality management and control.

\section{Conclusions}

France has high standards of higher education and research. Research institutions and HEls adapt and implement strategies that promote international attractiveness of the sector. Some of the strategic goals proposed at the national and institutional levels include strengthening national policies to improve the reception of international students, young researchers and staff; promoting outgoing mobility; introducing educational programs in foreign languages.

The higher education quality enhancement is being paid constant attention to at the national and institutional levels. Haut Conseil de l'évaluation de la recherche et de l'enseignement supérieur and Commission des Titres d'Ingénieur are authorized by French law to accredit programs in France and abroad. Their membership in numerous European and international networks testifies to a great degree of quality assurance internationalization in France.

Institutional practices are coordinated with the national strategies that are demonstrated by UL. UL has a comprehensive internal quality assurance system with the focus on internationalization and quality culture. Students have the possibility to spend one or more semesters at UL through a number of exchange programs. They are also invited to apply for one of the international curricula, where all or parts of the courses are taught in English. UL supports researchers in the internationalization of research, whether researches from abroad or a Lorraine researcher in search of international development, or mobility in the context of their research.

Délégation à l'Aide au Pilotage Et à la Qualité promotes a culture of continuous improvement and organizational development based on the tools of quality management and process control at the institutional level.

The following triggers for internationalization and quality enhancement in higher education of France have been identified: the legislative basis, internationalization strategies and quality assurance agencies at the national and institutional levels, networks of stakeholders involved in internationalization and quality assurance processes, participation in the international projects.

France's approach to higher education quality assurance and internationalization is a valuable example to be followed by the members of the EHEA.

EU Erasmus+ Program, participation in EDUQAS Project stimulate further development of QA systems at the national and institutional levels; wider participation of stakeholders in the quality 
enhancement and internationaliation; quality monitoring through stakeholders' surveys; monitoring graduates' career paths in partner countries.

\section{Бібліографічні посилання}

Дебич, М. А. (2019). Теоретичні засади інтернаціоналізації вищої освіти: міжнародний досвід : монографія. Ніжин : ПП Лисенко. URL: https://ihed.org.ua/wpcontent/uploads/2019/11/Debych M 2-12-2019 monogr disert.pdf

Academic Ranking of World Universities $2019 . \quad$ URL: http://www.shanghairanking.com/ARWU2019.html

Agence d'évaluation de la recherche et de l'enseignement supérieur (AERES). URL: https://www.rue-aef.com/exposant/institutionnels/aere/

Comité national d'évaluation (CNE). Les missions et les principes d'action. URL: https://www.cneevaluation.fr/fr/present/som mis.htm

Commission des Titres d'Ingénieur (CTI). Historie et la missions de la CTI. URL: https://www.cticommission.fr/la-cti/histoire-et-missions

De Wit, H., Hunter, F., Howard, L., \& Egron-Polak, E. (2015). Internationalisation of Higher Education. Study. Brussels, European Parliamentum. URL: https://www.europarl.europa.eu/RegData/etudes/STUD/2015/540370/IPOL STU(2015)540 370 EN.pdf

Erasmus+ K2A project «EDUQAS»: kick-off meeting in Craiova. URL: http://eduqas.dsum.edu.ua/2018/03/04/erasmus-k2a-project-eduqas-kick-off-meeting-incraiova/

European Quality Assurance Agency for Higher Education. Members. URL: https://enqa.eu/index.php/enqa-agencies/members/full-members/

European Approach for Quality Assurance of Joint Programmes, October 2014. URL: https://www.eqar.eu/assets/uploads/2018/04/02 European Approach QA of Joint Progr ammes v1 $0 . p d f$

Haut Conseil d'évaluation de la recherche et de l'enseignement supérieur (HCERES). URL: https://www.eqar.eu/register/agencies/agency/?id=29

Institute of International Education Project Atlas Infographics 2019. URL: https://www.iie.org/Research-and-Insights/Project-Atlas/Explore-Data/Infographics/2019-

Project-Atlas-Infographics

L'agence Erasmus+ France / Education Formation. URL: https://agence.erasmusplus.fr/lagenceerasmus/presentation-de-lagence-erasmus/son-role/

Leveratto, A., Schmitt, E., Barad, M. (2019). Following students' paths, while and after studying at Universite de Lorraine. URL: http://eduqas.dsum.edu.ua/wpcontent/uploads/2019/03/3 EduQAS Nancy-Observatory-OVU.pdf

Law on Higher Education and Research $2013 . \quad$ URL: https://en.wikipedia.org/wiki/Law on Higher Education and Research (France)

Loi Faure. URL: https://fr.wikipedia.org/wiki/Loi Faure

Loi Savary. URL: https://fr.wikipedia.org/wiki/Loi Savary

Paris Communiqué. Paris, May 25 $2018 . \quad$ URL: https://mon.gov.ua/storage/app/media/news/\%D0\%9D\%D0\%BE\%D0\%B2\%D0\%B8\%D0\%BD \%D0\%B8/2018/06/06/12/paris-communiqueenua2018.pdf

Sanlis, C. (2019). Quality approach in training at Université de Lorraine. URL: http://eduqas.dsum.edu.ua/wpcontent/uploads/2019/03/2 EduQAS nancy Quality approach trainingfields.pdf\%20http:/web.elth.ucv.ro/eduqas 
Sanlis, C., \& Pisarz, S. (2019). Self-assessment in training and external references. URL: http://eduqas.dsum.edu.ua/wpcontent/uploads/2019/03/9 EduQAS Nancy self assessment 3.pdf

Standards and Guidelines for Quality Assurance in the European Higher Education Area (ESG 2015). URL:

http://www.britishcouncil.org.ua/sites/default/files/standards-andguidelines for qa in the ehea 2015.pdf

The European Higher Education Area in 2018: Bologna Process Implementation Report (2018). EACEA/Eurydice. Luxembourg: Publications Office of the European Union. URL: http://eurydice.indire.it/wp-content/uploads/2018/05/Bologna-Report-2018.pdf

Université de Lorraine DAPEQ. URL: https://www.univ-lorraine.fr/content/aide-au-pilotage-et\%C3\%A0-la-qualit\%C3\%A9

Université de Lorraine. Inbound and outbound mobility. URL: http://www.univlorraine.fr/30ansErasmus/mobilite-entrante-et-sortante

Université de Lorraine. International Strategy. URL: http://welcome.univlorraine.fr/en/international-strategy

Université de Lorraine. Portrait. URL: http://www.univ-lorraine.fr/content/faire-dialoguer-lessavoirs-cest-innover.

Welcome to Université de Lorraine. URL: https://www.univ-lorraine.fr/content/venir-etudier-enlorraine

\section{References}

Debych, M. A. (2019). Teoretychni osnovy internatsionalizatsii vyshchoi osvity: mizhnarodnyi dosvid [Theoretical Bases for Higher Education Internationalization: International Experience] : monograph. Nizhyn : PP Lysenko. URL: https://ihed.org.ua/wpcontent/uploads/2019/11/Debych M 2-12-2019 monogr disert.pdf

Academic Ranking of World Universities $2019 . \quad$ URL: http://www.shanghairanking.com/ARWU2019.html

Agence d'évaluation de la recherche et de l'enseignement supérieur (AERES). URL: https://www.rue-aef.com/exposant/institutionnels/aere/

Comité national d'évaluation (CNE). Les missions et les principes d'action. URL: https://www.cneevaluation.fr/fr/present/som mis.htm

Commission des Titres d'Ingénieur (CTI). Historie et la missions de la CTI. URL: https://www.cticommission.fr/la-cti/histoire-et-missions

De Wit, H., Hunter, F., Howard, L., Egron-Polak, E. (2015). Internationalisation of Higher Education. Study. Brussels, European Parliamentm. URL: https://www.europarl.europa.eu/RegData/etudes/STUD/2015/540370/IPOL STU(2015)540 370 EN.pdf

Erasmus+ K2A project «EDUQAS»: kick-off meeting in Craiova. URL: http://eduqas.dsum.edu.ua/2018/03/04/erasmus-k2a-project-eduqas-kick-off-meeting-incraiova/

European Quality Assurance Agency for Higher Education. Members. URL: https://enqa.eu/index.php/enqa-agencies/members/full-members/

European Approach for Quality Assurance of Joint Programmes, October 2014. URL: https://www.eqar.eu/assets/uploads/2018/04/02 European Approach QA of Joint Progr ammes v1 0.pdf

Haut Conseil d'évaluation de la recherche et de l'enseignement supérieur (HCERES). URL: https://www.eqar.eu/register/agencies/agency/?id=29 
Institute of International Education Project Atlas Infographics 2019. URL: https://www.iie.org/Research-and-Insights/Project-Atlas/Explore-Data/Infographics/2019Project-Atlas-Infographics

L'agence Erasmus+ France / Education Formation. URL: https://agence.erasmusplus.fr/lagenceerasmus/presentation-de-lagence-erasmus/son-role/

Leveratto, A., Schmitt, E., \& Barad, M. (2019). Following students' paths, while and after studying at Universite de Lorraine. URL: http://eduqas.dsum.edu.ua/wpcontent/uploads/2019/03/3 EduQAS Nancy-Observatory-OVU.pdf

Law on Higher Education and Research 2013. URL:
https://en.wikipedia.org/wiki/Law on Higher Education and Research (France)

Loi Faure. URL: https://fr.wikipedia.org/wiki/Loi Faure

Loi Savary. URL: https://fr.wikipedia.org/wiki/Loi Savary

Paris Communiqué. Paris, May 20 2018. URL: https://mon.gov.ua/storage/app/media/news/\%D0\%9D\%D0\%BE\%D0\%B2\%D0\%B8\%D0\%BD \%D0\%B8/2018/06/06/12/paris-communiqueenua2018.pdf

Sanlis, C. (2019). Quality approach in training at Université de Lorraine. URL: http://eduqas.dsum.edu.ua/wpcontent/uploads/2019/03/2 EduQAS nancy Quality approach trainingfields.pdf\%20http:/web.elth.ucv.ro/eduqas

Sanlis, C., Pisarz, \& S. (2019). Self-assessment in training and external references. URL: http://eduqas.dsum.edu.ua/wpcontent/uploads/2019/03/9 EduQAS Nancy self assessment 3.pdf

Standards and Guidelines for Quality Assurance in the European Higher Education Area (ESG 2015). URL: $\quad$ http://www.britishcouncil.org.ua/sites/default/files/standards-andguidelines for qa in the ehea 2015.pdf

The European Higher Education Area in 2018: Bologna Process Implementation Report. (2018). EACEA/Eurydice. Luxembourg: Publications Office of the European Union. URL: http://eurydice.indire.it/wp-content/uploads/2018/05/Bologna-Report-2018.pdf

Université de Lorraine DAPEQ. URL: https://www.univ-lorraine.fr/content/aide-au-pilotage-et\%C3\%A0-la-qualit\%C3\%A9

Université de Lorraine. Inbound and outbound mobility. URL: http://www.univlorraine.fr/30ansErasmus/mobilite-entrante-et-sortante

Université de Lorraine. International Strategy. URL: http://welcome.univlorraine.fr/en/international-strategy

Université de Lorraine. Portrait. URL: http://www.univ-lorraine.fr/content/faire-dialoguer-lessavoirs-cest-innover.

Welcome to Université de Lorraine. URL: https://www.univ-lorraine.fr/content/venir-etudier-enlorraine

Дебич Марія

\section{Стимули для інтернаціоналізації та підвищення якості вищої освіти Франції}

\section{Анотація}

У статті проаналізовано статегії інтернаціоналізації та систему забезпечення якості Франції та Université de Lorraine. 3’ясовано, що цілі, запропоновані у національних та інституційних стратегіях інтернаціоналізації, включають посилення політики щодо покращення прийому міжнародних студентів, молодих дослідників та персоналу. 
Зазначено, що Вища рада із оцінювання досліджень і вищої освіти та Université de Lorraine $\epsilon$ партнерами проєкту «Впровадження системи забезпечення якості освіти через співпрацю університету-бізнесу-уряду у закладах вищої освіти» (Проєкт EDUQAS), спрямованого на вдосконалення систем забезпечення якості освіти шляхом розроблення ефективних внутрішніх стандартів якості, що сприяють кращому працевлаштуванню випускників у країнах-партнерах.

Вища рада із оцінювання досліджень і вищої освіти та Комісія із присвоєння спеціальності «інженер» уповноважена проводити міжнародні акредитації освітніх програм. Комісія з підтримки управління та якості Université de Lorraine пропагує культуру постійного вдосконалення та організаційного розвитку, що базується на інструментах управління якістю та контролю процесів забезпечення якості.

3'ясовано, що участь у проєкті EDUQAS стимулювала: подальший розвиток систем забезпечення якості на національному та інституційному рівнях; участь зацікавлених сторін у підвищенні якості та інтернаціоналізації вищої освіти; моніторинг якості вищої освіти шляхом опитування зацікавлених сторін; моніторинг кар'єрних шляхів випускників у країнах-партнерах.

Доведено, що законодавча база, стратегії інтернаціоналізації та агентства із забезпечення якості на національному та інституційному рівнях, мережі зацікавлених сторін, які беруть участь у процесах інтернаціоналізації та забезпечення якості, участь у міжнародних проєктах є стимулами для інтернаціоналізації та підвищення якості вищої освіти у Франції.

Ключові слова: стратегія інтернаціоналізації, система забезпечення якості, Комісія з підтримки управління та якості (DAPEQ), проєкт EDUQAS, звіт про самооцінювання, освітня програма.

\section{Інформація про автора:}

Дебич Марія

- Доктор педагогічних наук, доцент, с.н.с.

- Україна

- Інститут вищої освіти НАПН України, провідний науковий співробітник

- ORCIDiD 0000-0002-3836-1915

- E-mail: m.debych@ihed.org.ua

Debych Mariia

- Doctor Habilitated in Educational Sciences, Associate Professor, Senior Researcher

- Ukraine

- Institute of Higher Education of the National Academy of Educational Sciences of Ukraine, leading researcher 